\title{
Evaluation of Bioagents and Biopesticides against Colletotrichum lindemuthianum and its Integrated Management in Common Bean
}

\author{
Bilal Ahmad PADDER, Prem Nath SHARMA, Renu KAPIL, \\ Anju PATHANIA, Om Prakash SHARMA \\ CSK HP Agricultural University, Palampur-176062 (HP), Molecular Plant Pathology \\ Laboratory,Department of Plant Pathology, India; bapadder@rediffmail.com
}

\begin{abstract}
Three bioagents (Trichoderma viride, T. harzianum and Gliocladium virens) and five biopesticides (Achook, Neemgold, Wannis, Spictaf and Neemazal) were evaluated under in vitro and in vivo conditions against Colletotrichum lindemuthianum. All the three antagonistic fungi caused significant inhibition of mycelial growth, maximum being with T. viride (69.21\%) followed by T. harzianum (64.20\%). Among the biopesticides tested at four concentrations, Wanis applied @ $1000 \mu \mathrm{l} / \mathrm{ml}$ caused maximum inhibition of 82.12 per cent followed by Spictaf (52.85\%).T. viride and Wanis @ $1000 \mu \mathrm{l} / \mathrm{ml}$ were most effective in reducing the seed borne infection. Integration of bioagents with Bavistin showed that disease can be effectively managed with seed dressing either with Bavistin or biopesticide followed by foliar treatment with fungicide or biopesticide.
\end{abstract}

Keywords: bean anthracnose, biopesticides, disease management

\section{Introduction}

Bean anthracnose caused by Colletotrichum lindemuthianum (Sacc. and Magn.) Bri and Cav. is a cosmopolitan seed borne disease. Infection of a susceptible cultivar in favourable conditions leading to an epidemic may result in $100 \%$ yield losses (Araya, 1989; Sharma et al., 1994; Sharma and Sugha, 1995; Somavilla and Prestes, 1999; Fernandez et al., 2000). Despite the availability of management practices like seed and foliar treatment with fungicides, crop rotation, use of certified seed and genetic resistance etc, bean anthracnose is still of regular occurrence in most of the areas. Best strategy to manage disease is planting resistant cultivars, which is most effective, least expensive and easiest for farmers to adopt. However, high pathogenic variability present in the pathogen population (Pastor-Corrales et al., 1995; Sharma et al., 1999; Mahuku and Riascos, 2004; Sharma et al., 2007; Padder et al., 2007) renders their use ineffective due to continuous breakdown of the resistance mainly in recommended cultivars with good agronomic and marketability traits (Sharma et al., 1994; Kumar et al., 1997).

In present day agriculture, farmers use integrated crop production strategies involving various inputs, practices and means of managing biotic and abiotic stresses. However, uses of chemicals dominate all other inputs, thus leads to degradation of the environment, development of fungicidal resistance along with their harmful effect on human beings and beneficial organisms. Bavistin being highly effective against the anthracnose is mostly used both for seed treatment and foliar sprays in high rainfall conditions which could create problem of fungicidal resistance in the pathogen in due course of time, it is important to find out an alternative to avoid this risk. So, use of non chemical ecofriendly means of control i.e. biocontrol and biopesticides have emerged as a viable alternative under such conditions (Singh, 2006). The presence of naturally occurring microorganisms with antifungal property has been well recognized and documented, but very few of them have been studied extensively in case of bean anthracnose. These bioagents have been tested against an array of Colletotrichum species infecting many commercially important crop plants (Singh, 1985; Silva and Pascholati, 1992). Hence in the present study, biocontrol agents, biopesticides along with fungicide (Bavistin) were evaluated under in vitro conditions and their integration was studied under in vivo to evolve an effective management strategy.

\section{Materials and methods}

In vitro evaluation of bioagents and biopesticides

Antagonistic activity of bioagents viz., Trichoderma viride, T. harzianum and Gliocladium virens against bean anthracnose pathogen was tested (local strains) on PDA using dual culture technique (Huang and Hau, 1976). Inhibition of pathogen by bioagent over control was calculated by using the formula as described by Vincent (1947).

Five biopesticides viz., Neemgold, Achook EC, Wanis, Neemazal and Spictaf along with Bavistin 50WP as a standard check were evaluated under in vitro conditions at 4 different concentrations $(250 \mathrm{ppm}, 500 \mathrm{ppm}, 750 \mathrm{ppm}$ and $1000 \mathrm{ppm}$ ) using poison food technique. All the bioagents and a few biopesticides (Neemgold, Wanis and Spictaf) were evaluated at two different concentrations (750 and $1000 \mathrm{ppm}$ ) against seed borne infection of anthracnose 
under pot culture conditions. Naturally infected seeds of common bean variety Jawala were dressed with spore mass slurry. The treated seeds were sown in iron trays filled with sterilized sand and incubated in growth chamber at $22 \pm$ $1^{\circ} \mathrm{C}$ with 12 hour photoperiod with 90 per cent relative humidity for 48 hrs. Each treatment was replicated thrice. Seeds without treatment served as control. Efficacy of three biopesticides was tested at two different concentrations (750 ppm and $1000 \mathrm{ppm}$ ) against seed borne infection of bean anthracnose. Anthracnose affected seeds of Jawala variety were dipped in different concentrations of biopesticides for 5 minutes and sown in the trays having sterilized sand. The trays were incubated at $22 \pm 1^{\circ} \mathrm{C}$ in growth chamber (Saveer Biotech) and the humidity was maintained above 90 per cent using humidifier. All the treatments were replicated thrice and seed treatment with Bavistin was kept as check. Data on disease severity and Incidence was recorded.

\section{Integrated management of bean anthracnose}

In field experiments, most effective biocontrol agent (T. viride) and biopesticide (Wanis @ 1000 ppm) were integrated with fungicide Bavistin and resistant cultivar Baspa, which possess high field resistance, was used as check. Field trials were laid at Mountain Agricultural Research and Extension Centre (MAREC) Sangla (Kinnaur) and in farmer's field at Ghiyaghi (Kullu) hotspots of bean anthracnose for consecutively 2 years. Seeds of highly susceptible local cultivars commonly grown by the farmers in Sangla and Ghiyaghi areas were used for experimentation purpose with a view to get maximum disease. Naturally infected seed was used for both the field trials. Two sprays of fungicide (Bavistin @ 0.1\%) and biopesticide (Wanis@ $1 \%)$ were given at 45 and 60 days after sowing, respectively. Both the field trials were laid in Completely Randomized Block Design with three replications for each treatment. Size of plot at MAREC, Sangla was 2 X $2 \mathrm{~m}^{2}$ while the size of plot at Ghiyaghi was 2 X $5 \mathrm{~m}^{2}$. Ten plants per treatment per replication were randomly selected for recording the data on disease severity and disease index following the formula of Mickwney (1923).

\section{Results}

Antagonistic activity of three bioagents (Trichoderma viride, T. harzianum and Gliocladium virens) and five neem based biopesticides (Achook, Neemazal, Neemgold, Spictaf and Wanis) against C. lindemuthianum in dual culture and poisoned food technique is presented in Fig 1 and 2. All the three antagonistic fungi caused significant inhibition of mycelial growth ranging from 57.45 to 69.21 per cent. Maximum inhibition of mycelial growth was obtained with T. viride (69.21\%) followed by $T$. harzianum (64.20\%) though both were statistically at par with each other. Effect of biopesticides on mycelial growth of C. lindemuthianum revealed (Fig. 2) that almost all biopesti- cides inhibited the mycelial growth over control, however, Wanis applied @ $1000 \mu \mathrm{l} / \mathrm{ml}$ caused maximum inhibition of 82.12 per cent followed by Spictaf $(52.85 \%)$ which was statistically at par with Achook (51.22\%) and Neemazal (50.40\%). Neemgold at $1000 \mu \mathrm{l} / \mathrm{ml}$ was least effective. At $750 \mu \mathrm{l} / \mathrm{ml}$ concentration. Wanis, Spictaf and Neemazal caused 43.04 to $53.98 \%$ inhibition of mycelial growth. However, Bavistin used as a check was most effective over all biopesticides in controlling the growth of the pathogen.

Antagonistic activity of three bioagents viz., T. viride, T. harzianum and G. virens on seed borne infection of $C$. lindemuthianum tested under pot culture revealed that seed treatment with biocontrol agent had significant effect on seed borne infection as compared to check. Seeds treated with T. viride showed only 9.87 per cent seed borne infection as compared to 49.56 per cent in control causing 80.08 per cent reduction, followed by $T$. harzianum and G. virens which caused 74.88 and 68.34 per cent reduction though both were statistically at par with each other (Tab. 1). Three biopesticides viz., Neemgold, Spictaf and Wanis applied at 750 and $1000 \mu \mathrm{l} / \mathrm{ml}$ concentration also showed similar effects on seed borne infection (Tab. 2). However, bavistin used as check caused maximum reduction of 88.91 per cent. Wanis applied @ $750 \mu \mathrm{l} / \mathrm{ml}$ and $1000 \mu \mathrm{l} / \mathrm{ml}$ showed maximum 74.65 and 81.95 per cent reduction in seed borne infection followed by Spictaf (57.32 and 64.15\%). Most effective bioagent and botanical found effective under in vitro conditions were used to develop an integrated disease management module against bean anthracnose using T. viride, Wanis @ $1000 \mu \mathrm{l} / \mathrm{ml}$ and Bavistin as seed treatment and foliar sprays. It is evident from the tab. 3 that majority of treatments used either alone or in combination caused significant reduction in disease incidence as well as terminal severity at both the locations. However, seed treatment alone was not as ef-

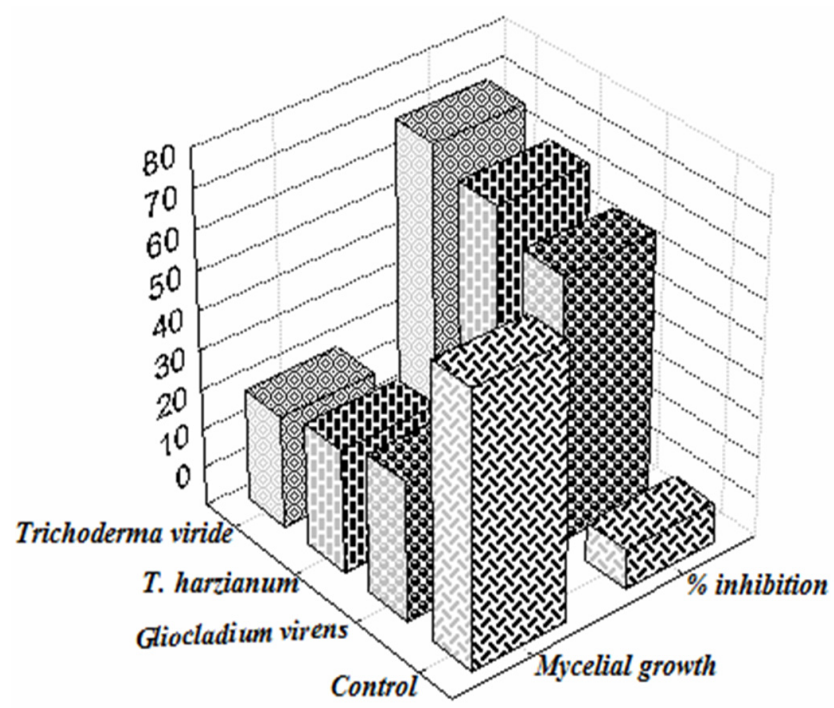

Fig. 1. Effect of bioagents on mycelial growth of C. lindemuthianum 
74

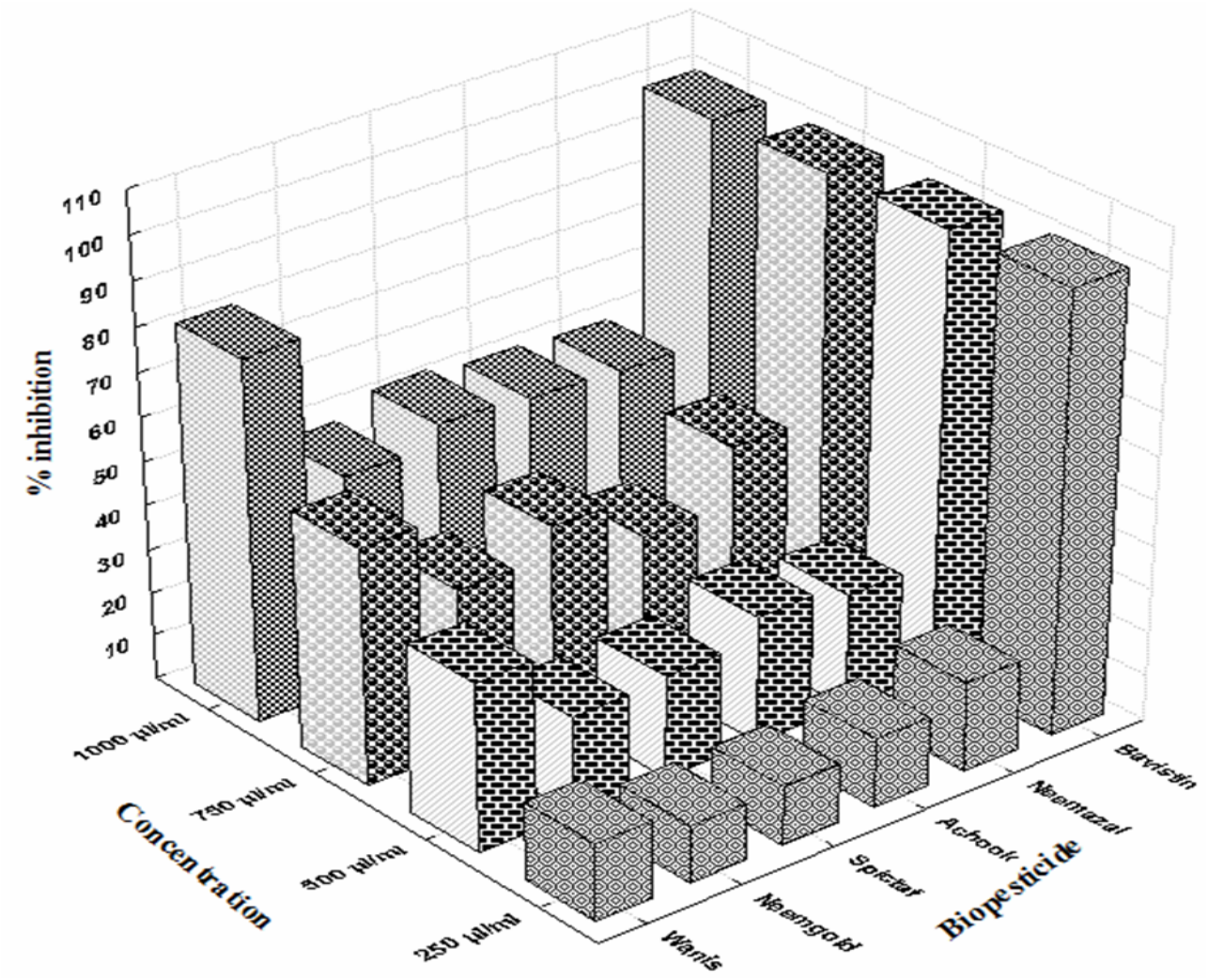

Fig. 2. Effect of biopesticides on mycelial growth of C. lindemuthianum

Tab. 2. Effect of biopesticides on seed borne infection of $C$. lindemuthianum*

Tab. 1. Effect of bioagents on seed borne infection of $C$. lindemuthianum *

\begin{tabular}{ccc}
\hline Bioagents & \% seed borne infection & \% inhibition \\
\hline Trichoderma viride & $9.87(18.31)$ & 80.08 \\
T. harzianum & $12.45(20.66)$ & 74.88 \\
Gliocladium virens & $15.69(23.33)$ & 68.34 \\
Control & $49.56(44.47)$ & - \\
C.D $(\mathrm{p}=0.05 \%)$ & 2.64 & \\
\hline
\end{tabular}

${ }^{*}$ Average of three replications; Figures in parentheses are arc sine transformed values

\begin{tabular}{ccccc}
\hline \multirow{2}{*}{ Treatment } & \multicolumn{2}{c}{ \% seed borne infection } & \multicolumn{2}{c}{ \% inhibition } \\
\cline { 2 - 5 } & $750 \mu \mathrm{l} / \mathrm{ml}$ & $1000 \mu \mathrm{l} / \mathrm{ml}$ & $750 \mu \mathrm{l} / \mathrm{ml}$ & $\begin{array}{c}1000 \\
\mu \mathrm{l} / \mathrm{ml}\end{array}$ \\
\hline Neemgold & $27.42(31.56)$ & $24.54(29.68)$ & 48.02 & 51.22 \\
Spictaf & $22.56(28.34)$ & $18.91(25.72)$ & 57.32 & 64.15 \\
Wanis & $13.37(21.44)$ & $9.5217 .95)$ & 74.65 & 81.95 \\
Bavistin & $5.85(13.99)$ & $5.85(13.96)$ & 88.91 & 88.91 \\
\hline Control & $52.75(46.57)$ & $52.75(46.57)$ & & \\
\hline $\begin{array}{c}\mathrm{CD}= \\
(\mathrm{p}=0.05 \%)\end{array}$ & 2.19 & 2.22 & & \\
\hline
\end{tabular}

${ }^{*}$ Average of three replications; Figures in parentheses are arc sine transformed values

Tab. 3. Integrated management of bean anthracnose under field conditions

\begin{tabular}{|c|c|c|c|c|c|c|}
\hline \multirow[b]{2}{*}{ Treatments } & \multicolumn{3}{|c|}{ Location I } & \multicolumn{3}{|c|}{ Location II } \\
\hline & $\begin{array}{l}\text { \% Disease } \\
\text { incidence }\end{array}$ & $\begin{array}{l}\text { \% Disease } \\
\text { severity** }\end{array}$ & $\begin{array}{c}\text { Yield/plot } \\
(\mathrm{q} / \mathrm{ha})^{*}\end{array}$ & $\begin{array}{l}\text { \% Disease } \\
\text { incidence }\end{array}$ & $\begin{array}{c}\text { \% Disease } \\
\text { severity }\end{array}$ & $\begin{array}{l}\text { Yield/pot } \\
(\mathrm{Kg})^{*}\end{array}$ \\
\hline Seed treatment with bioagent ${ }^{a}$ & $63.10(52.59)$ & $33.30(35.24)$ & 1.27 & $25.64(30.42)$ & $17.47(24.71)$ & 4.68 \\
\hline Seed treatment with biopesticide ${ }^{\mathrm{b}}$ & $59.70(50.60)$ & $32.07(34.49)$ & 1.38 & $24.97(29.98)$ & $16.21(23.74)$ & 4.77 \\
\hline Seed treatment with fungicide ${ }^{c}$ & $60.71(51.18)$ & $32.85(34.97)$ & 1.26 & $21.22(27.43)$ & $14.14(22.05)$ & 4.83 \\
\hline Seed treatment with bioagent + spray with biopesticide & $45.11(42.36)$ & $26.19(30.78)$ & 1.30 & $16.63(24.07)$ & $9.31(17.76)$ & 4.94 \\
\hline Seed treatment with bioagent + spray with fungicide & $43.37(41.19)$ & $23.11(28.73)$ & 1.43 & $14.06(22.02)$ & $9.07(17.52)$ & 5.25 \\
\hline Seed treatment with biopesticide + spray with fungicide & $40.23(39.36)$ & $20.72(27.08)$ & 1.79 & $12.09(20.35)$ & $7.86(16.28)$ & 5.10 \\
\hline Seed treatment and spray with fungicide & $39.33(38.84)$ & $18.84(25.72)$ & 1.83 & $10.45(18.86)$ & $7.77(16.18)$ & 5.13 \\
\hline Control & $82.45(65.23)$ & $47.59(43.62)$ & 0.73 & $63.47(44.29)$ & $34.73(28.89)$ & 2.98 \\
\hline Check (Baspa) & $0.00(0.85)$ & $0.00(0.85)$ & 2.74 & $0.00(0.85)$ & $0.00(0.85)$ & 5.45 \\
\hline $\mathrm{CD}=(\mathrm{p}=0.05 \%)$ & 2.91 & & 0.44 & 3.73 & 2.47 & 0.56 \\
\hline
\end{tabular}

${ }^{*}$ Average of three replications; $\mathrm{a}=$ T. viride $; \mathrm{b}=$ Wanis; $\mathrm{c}=$ Bavistin; ${ }^{*}$ Disease severity on pods; Figures in parenthesis are arc sine Transformed values 
fective as combination of seed treatment alongwith foliar sprays. Minimum disease incidence and severity of 39.33 and 18.84 per cent was recorded in plots when bavistin was used both for seed treatment and foliar sprays. However, it was statistically at par with biopesticide seed treatment and foliar sprays with fungicide (40.23 and 20.72\%). Cultivar Baspa which possesses high field resistance did not show any infection. There was significant effect of disease on yield per plot.

Field trial conducted in Ghiyaghi (location II) area showed almost similar trend of disease (Tab. 3). However, incidence and severity values were significantly low as compared to Sangla. Minimum incidence (10.45\%) and severity $(7.77 \%)$ was recorded in seeds treated with Bavistin and followed by sprays of fungicide which was statistically at par with seed treatment with biopesticide followed by spray with Bavistin (12.09 and 7.86\%). Seed treatment alone with biocontrol agent, biopesticide and fungicide showed high incidence and severity ranging from 21.22 to 25.64 and 14.14 to 17.47 per cent, which were statistically at par with each other. The maximum yield per plot was recorded in Baspa check $(5.45 \mathrm{Kg})$ which was at par with the plots having seed treatment with biocontrol agent, biopesticide or fungicide followed by foliar spray either with Bavistin or biopesticide.

\section{Discussion}

Excessive use of chemicals in plant disease management has resulted in number of problems related to fungicide resistance, damage to non target flora and fauna and other useful organisms along with hazardous effects of residue on environment have become the main concern of scientists at present (Singh, 2006). Bean anthracnose a cosmopolitan seed borne disease can effectively be controlled if the healthy or treated seed is used for planting. Hence, in the present investigation biocontrol and biopesticide approaches were evaluated along with fungicide/chemical to evolve ecofriendly module for its management. In the present investigation all the three biocontrol agents viz., T. harzianum, T. viride and G. virens significantly inhibited the mycelial growth and seed borne infection of $C$. lindemuthianum. Antagonism with Trichoderma species against an array of phytopathogens has been reported by many workers (Dennis and Webster, 1971; Mortuza, 1997; Kumar and Satyavir, 1998; Kaur et al., 2006). Most of them have been reported to produce volatile and nonvolatile compounds that inhibit the growth of fungal phytopathogens. Besides, production of various antibiotics along with large number of volatile secondary metabolites plays an important key role in biocontrol (Vey et al., 2001). The capacity shown by these bioagents to overgrow colonies of $C$. lindemuthianum and coil around its hyphae suggests hyphal interaction mechanism. Hyperparasitism along with the production of secondary metabolites and antibiotics might have attributed in inhibition of mycelial growth and seed borne infection, as the Trichoderma species either added to the soil or applied as seed treatment, grow rapidly along with the developing root system of the treated plant (Harman, 2000; Howell et al., 2000; Adebanjo and Bankole, 2004).

Among various biopesticides (Neemgold, Neemazal, Wanis, Achook and Spictaf) Wanis applied @ $1000 \mu \mathrm{l} /$ $\mathrm{ml}$ inhibited the mycelial growth and seed borne infection significantly over control. Similar effects of Azadirachta indica extracts have also been observed by Amadioha and Obi (1998) against C. lindemuthianum. Similarly spraying of Ocimum sanctum and citrus lemon extracts reduced the bean anthracnose infection under glass house conditions (Amadioha, 1999). Wanis containing monoterpenes as active ingredient might have attributed for the control of pathogen whereas other biopesticides contain Azadarictin as active molecule reported to possess antifungal properties against many plant pathogenic fungi.

Results of integrated disease management experiments including use of fungicide, biocontrol agent, biopesticide and resistant variety revealed that seed treatment and spray with fungicide (Bavistin) was most effective in reducing the incidence and severity of the disease followed by seed treatment with biopesticide (Wanis) and spray with fungicide. Hegde et al. (2001) evaluated biocontrol agent $P$. fluorescens along with fungicides under green house conditions against chilli and observed that $P$. fluorescens significantly decreased the seedling mortality in chilli which was at par with Captan. Joshi and Tripathi (2002) investigated the cultural, biological and chemical methods of management to control C. capsici on urd bean and reported that $T$. harzianum and $G$. virens effectively controlled the anthracnose disease under field conditions. Esfahani and Bak (2004) reported that seed treatment of potato with $T$. harzianum not only reduced the black dot disease incited by $C$. coccodes but also increased various plant growth factors including the yield. In this study seed treatment with biocontrol agent was not effective which could be due to least rhizosphere colonization as the bioagent to be effective must colonize rhizospere beyond $2 \mathrm{~cm}$ depth from the seed for proliferate or to a concentration that exceeds the initial population coated on the seed (Ahmad and Baker, 1987; Harman, 2000; Howell, 2003). In the present investigation an attempt was made to devise integrated disease management with the aim to reduce fungicide resistance in the pathogen. However, for development of such a module large number of Trichoderma species are to be isolated from the rhizoshere of beans and their screening along with the exploitation of phylloplane microorganisms.

\section{References}

Adebanjo, A. and S. A. Bankole (2004). Evaluation of some fungi and bacteria for biocontrol of anthracnose disease of cowpea. Journal of Basic Microbiology 44:3-9.

Ahmad, J. S. and R. Baker (1987). Competitive saprophytic 
76

ability and cellulytic activity of rhizosphere-competitive mutants of Trichoderma harzianum. Phytopathol. 77:358 362.

Amadioha, A. C. and V. I. Obi (1998). Fungitoxic activity of extracts from Azadirachta indica and Xylopia aethiopica against Colletotrichum gloeosporioides, agent of passion fruit anthracnose. Summa Phytopathologica 24:180-183.

Amadioha, A. C. (1999). Evaluation of some plant extracts against Colletotrichum lindemuthianum in cowpea. Archives of Phytopathology and Plant Protection 32:141-149.

Araya, C. M. (1989). La antracnosis del frijol (Phaseolus Vulgaris L.) en Costa Rica. Manejo Integrado de Plagas (Costa Rica) 13:83-91.

Dennis, C. and J. Webster (1971). Antagonistic properties of species groups of Trichoderma III. Production of volatile antibiotics. Transactions of British Mycological Society 51:363-369.

Esfahani, A. N. and A. M. Bak (2004). Biological and cultural control of black dot disease of potato. Journal of Science and Technology of Agriculture and Natural Resources 8:193207.

Fernandez, M. T., M. Fernandez, A. Casares, R. Rodriguez and M. Fueyo (2000). Bean germplasm evaluation for anthracnose resistance and characterization of agronomic traits. A new Physiological strain of Colletotrichum lindemuthianum infecting Phaseolus vulgaris L. in Spain. Euphytica 114:143-149.

Harman, G. E. (2000). Myths and dogmas of biocontrol: Changes in perception derived from research on Trichoderma harzianum T-22. Plant Dis. 84:377-391.

Hegde, G. M., K. Srikant and S. Kulkarni (2001). Seed treatment to control damping off of chilli caused by Colletotrichum capsici (Syndow) Butler and Bisby. Karnataka Journal of Agricultural Science 14:829-830.

Howell, C. R., L. E. Hanson, R. D. Stipanovic and L. S. Puckhaber (2000). Induction of terpenoid synthesis in cotton roots and control of Rhizoctonia solani by seed treatment with Trichoderma virens. Phytopathology 90:248-252.

Howell, C. R. (2003). Mechanism employed by Trichoderma species in the biological control of plant diseases: The history and evolution of current concepts. Plant Dis. 87:4-10.

Huang, H. C. and J. A. Hau (1976). Penetration and infection of Sclerotinia sclerotiorum by Coniothyrium minitans. Can. J. Bot. 54:406-410.

Joshi, D. and H. S. Tripathi (2002). Cultural, biological and chemical control of anthracnose of Urdbean. Mycology and Plant Pathology 32:52-55.

Kaur, M., O. P. Sharma and P. N. Sharma (2006). In vitro effects of Trichoderma species on Colletotrichum capsici causing fruit rot of chilli (Capsicum annuum L.) Indian Phytopath. 59:243-245.

Kumar, A. and Satyavir (1998). Evaluation of biocontrol agents against red rot (Colletotrichum falcatum) of sugarcane. Association of Applied Biologists 72-73 pp.
Mahuku, G. S. and J. J. Riascos (2004). Virulence and molecular diversity within Colletotrichum lindemuthianum isolates from Andean and Mesoamerican bean varieties and regions. Eur. J. Plant Pathol. 110:253-263.

Mickinney, H. H. (1923). Influence of soil temperature and moisture on infection of wheat seedling by Helminthosprium sativum. Journal of Agricultural Research 26:195-217.

Mortuza, G. (1997). Effect of antagonists, alum and ultraviolet irradiation on major fruit rots of banana (Musa sapientum L.). College Languna, April 1997.

Padder, B. A, P. N. Sharma, O. P. Sharma and V. Kapoor (2007). Genetic Diversity and gene flow estimates among five populations of Colletotrichum lindemuthianum across Himachal Pradesh-a North -Western state of India. Physiological and Molecular Plant Pathology and Molecular Plant Pathology 70:8-12.

Pastor-Corrales, M. A., M. M., Otoya, A. Molina and S. P. Singh (1995). Resistance to Colletotrichum lindemuthianum isolates from Middle America and Andean South America in different common bean races. Plant Dis. 76:63-67.

Sharma, P. N., A. Kumar, O. P. Sharma, D. Sud and P. D. Tyagi (1999). Pathogenic variability in Colletotrichum lindemuthianum and evaluation of resistance in Phaseolus vulgaris in the north-western Himalayan region of India. J. Phytopathol. 147:41-45.

Sharma, P. N., B. A. Padder, O. P. Sharma, A. Pathania and P. Sharma (2007). Pathological and molecular diversity in Colletotrichum lindemuthianum across Himachal PradeshA north-western state of India. Austr. Plant Pathol. 36:191197.

Sharma, P. N., O. P. Sharma and P. D. Tyagi (1994). Status and distribution of bean anthracnose in Himachal Pradesh. Himachal journal of Agricultural Research 20:91-96.

Sharma, P. N. and S. K. Sugha (1995). Management of bean anthracnose through chemicals. Indian Phytopathol. 48:304-307.

Silva, S. R. D. A. and S. F. Pascholati (1992). Saccharomyces cerevisiae protects maize plants under green house conditions against Colletotrichum graminicola. Z Pflanzinakarankeiten and Pflazenschlutz 99:159-167.

Singh, H. B. (2006). Trichoderma: A boon for biopesticide industry. Mycology and Plant Pathology 36:373-384.

Singh, R.S.(1985). Use of Epicocumpurpurescena as an antagonist against Macroohomina phaseolina and Colletotrichum capsici. Indian Phytopathol. 38:258-262.

Somavilla, L. L. and A. M. Prestes (1999). Identification of Colletotrichum lindemuthianum pathotypes occurring in some bean production regions of Rio Grande do Sul. Fitopatologia Brasileira 24:416-421.

Vey, A., R. E. Hoagland and T. M. Butt (2001). Toxic metabolites of fungal biocontrol agents. Fungi as biocontrol agents: Progress, problems and potential. Butt TM, Jackson C, Magan N, eds. Pp 311-346. CAB International, Bristol.

Vincent, J. M. (1947). Distortion of fungal hyphae in the presence of certain inhibitors. Nature 159:350. 